\title{
BAHASA SATIRE DALAM MEME MEDIA SOSIAL
}

\author{
Satire in \\ Social Media Meme
}

Ni Nyoman Ayu Suciartini

Institut Teknologi dan Bisnis ITB STIKOM Bali

Jalan Raya Puputan Renon Denpasar

Posel: uci_geg@yahoo.com

\begin{abstract}
Abstrak
Gaya satire dipilih untuk mengungkapkan sindiran dan kritik secara eksplisit. Dalam gaya berkomunikasi di media sosial, satire pun digunakan dalam pembuatan meme. Fokus penelitian ini adalah mengungkap bagaimana satire politik diwacanakan dalam meme di media sosial. Adapun tujuan penelitian ini adalah untuk mengkaji lebih dalam bagaimana wacana satire tersebut tertuang dalam teks-teks bergambar ataupun murni teks dalam meme media sosial. Penelitian ini menjadi menarik karena gaya satire humor yang terdapat dalam meme menjadi respons politik, ekonomi, pendidikan, budaya, dan lain-lain yang efektif, absurd, yang mampu menggeser, menghilangkan, kemudian membalikkan dan memunculkan wacana baru. Penelitian ini menggunakan analisis wacana kritis Norman Fairclough yang memiliki identifikasi bahwa wacana dapat berupa rangkaian ujar secara lisan dan tulisan atau rangkaian tindak tutur. Melalui analisis ini ditemukan bahwa satire dalam meme di media sosial digunakan dalam bentuk menyindir dan mengkritik halhal yang sedang viral dan bagaimana isu tersebut memengaruhi media sosial hingga dunia senyatanya. Meme dilihat bukan sebagai teks yang diam, pasif, dan selesai begitu diproduksi. Sebaliknya, meme adalah strategi yang dinamis dan bergerak, lewat satire.
\end{abstract}

Kata kunci: satire, meme, media sosial

\begin{abstract}
The satire style was chosen to express satire and criticism explicitly. In the style of communicating on social media, satire is also used in making memes. The problem with this research is how is satire language in meme culture on social media? The focus of this research is to reveal how political satire is discussed in memes on social media. The purpose of this study is to examine more deeply how the satire discourse is contained in pictorial texts or purely texts in social media memes. This research is interesting because the satire humor style contained in memes becomes an effective, absurd political, economic, educational, cultural, and other response that is able to shift, eliminate, then reverse and bring up new discourses. This study uses a critical discourse analysis by Norman Fairclough which has an identification that the discourse can be a series of verbal and written words or a series of speech acts. With this knife of analysis, it was found that satire in memes on social media is used in the form of satire and criticism of things that are being viral and how these issues affect social media to the real world. Memes are not seen as silent, passive, and finished texts as they are produced. Memes, on the other hand, are dynamic and moving strategies, through comedysatire.
\end{abstract}

Keywords: satire, meme, social media

\section{Pendahuluan}

Bahasa memiliki kekuatan yang bisa diibaratkan sebagai dua sisi mata uang. Di satu sisi, bahasa dapat menjadi daya tarik seseorang. Di sisi lain, bahasa dapat menjadi bumerang bagi pemakainya. Bahasa memegang peranan penting dalam menentukan kesuksesan sebuah komunikasi. Penting kiranya memahami pemakaian bahasa yang ditunjang oleh bahasa nonverbal agar komunikasi dapat berjalan dengan 
efektif dan terarah. Dalam hal menyampaikan kritik pun, bahasa memegang peranan penting. Tidak melulu kritik harus disampaikan dengan bahasa yang keras cenderung kasar. Kritik akan lebih efektif jika disampaikan lewat bahasa yang santai, lugas, tetapi tetap mengena sebagai sebuah kritik atau sindiran kepada pihak-pihak tertentu. Namun, banyak orang yang kurang dapat membungkus bahasa dalam penyampaian kritik agar tidak terkesan menggurui atau menjatuhkan. Banyak alternatif penggunaan bahasa yang santun dalam mengkritik atau menyindir. Salah satu di antaranya, yaitu dengan memanfaatkan bahasa satire sebagai gaya dalam mengkritik sesuatu.

Tulisan dengan nada mengkritik dapat disampaikan, baik dalam bentuk kalimat pendek maupun panjang di media online, media sosial, atau jejaring lainnya yang dirasakan efektif dan bermanfaat. Media komunikasi yang terbaru yang digunakan sebagai penyampaian kritik atau persemaian ide lainnya yang sedang hangat digeluti, yaitu penggunaan kritik lewat gaya meme.

Penelitian ini berfokus pada mengeksplorasi wacana dalam bentuk meme yang bersifat satire. Peneliti memilih meme di media social sebagai sumber data sebab meme dianggap efektif sebagai media komunikasi yang berisikan sifat jenaka dan sarat akan kritikan atau sindiran yang kreatif. Dalam hal ini wacana yang diteliti adalah wacana dalam meme di media sosial.

Meme dikenal luas di media sosial menampilkan kombinasi antara gambar foto, gabungan gambar dengan teks, kartun dengan teks, atau jenis lainnya yang kerap menyindir sesuatu yang sedang menjadi perbincangan hangat di dunia maya. Meme merupakan respons kreatif yang diciptakan oleh kalangan tertentu yang mungkin merasa gerah atau perasaan lainnya yang dicurahkan dalam bentuk parodi atau komedi tertentu untuk menanggapi isu hangat yang sedang terjadi.

Meme yang beredar di media sosial sungguh menggelitik dan layak untuk dikaji sebagai sebuah media penyampaian kritik yang sangat efektif, terlebih lagi didukung dunia digital yang serba cepat, serba viral.

Bahasa satire kini banyak ditemukan, khususnya di media sosial sebagai media yang dianggap ampuh untuk menyampaikan kritik atau sindiran. Hal ini menjadi menarik sebab penggunaan bahasa satire ini membuat munculnya diksi atau pilihan kata, kalimat, jargon, yang viral dan fenomenal di masyarakat. Hal ini menarik untuk diteliti sebab meme di media sosial dapat menjadi sindiran, kritikan juga hiburan terkait dengan beragam hal yang sedang viral.

Untuk mendukung penelitian ini dgunakan kajian pustaka berupa penelitian sejenis. Penelitian terdahulu terkait dengan penggunaan bahasa satire pernah dilakukan dengan judul Satire Politik dalam Lagu "Andai Ku Gayus Tambunan" memaparkan bahwa pesan satire dalam lagu "Andai $\mathrm{Ku}$ Gayus Tambunan" ini setidaknya mengangkat tiga hal penting. Pertama, tentang ketidakberdayaan masyarakat kelas proletar berhadapan dengan ketidakadilan hukum. Kedua, masalah moralitas dan skandal terselubung aparat penegak hukum dan pemilik kekuasaan. Ketiga, adanya hubungan antara struktur kekuasaan yang korup dan tuntutan publik. Penelitian lainnya, yaitu penelitian berjudul "Wacana Satire Politik dalam Situs Mojok.co yang menyatakan bahwa gaya penulisan di situs mojok.co ini memang bernada satire, menghibur dan terdapat banyak kritik. Setiap kontributor yang menulis wajib mengikuti gaya satire yang diusung berdasarkan isu-isu tertentu. Berdasarkan penelitian terdahulu sebagai kajian literatur terdahulu, penelitian dengan judul "Bahasa satire dalam kultur meme di media sosial" ini memiliki kebaharuan dan penting dilakukan. Perbedaan penelitian ini terletak pada objek penelitiannya, yaitu mengangkat satire dalam meme yang beredar di media sosial. Berdasarkan latar belakang yang telah diuraikan, dapat dirumuskan masalah, yaitu bagaimanakah analisis bahasa satire dalam meme di media sosial? Fokus penelitian ini adalah mengungkap bagaimana satire politik diwacanakan dalam meme di media sosial. Adapun tujuan penelitian ini adalah untuk mengkaji lebih dalam bagaimana wacana satire tersebut tertuang dalam teks-teks bergambar ataupun murni teks dalam meme media sosial. Penelitian ini menjadi menarik karena gaya satire humor yang terdapat dalam meme menjadi respons politik, ekonomi, pendidikan, budaya, dan lain-lain yang efektif, absurd, yang mampu menggeser, menghilangkan, kemudian membalikkan dan memunculkan wacana baru. Penelitian ini menggunakan analisis wacana kritis 
Norman Fairclough. Penelitian ini menggunakan rancangan penelitian kualitatif yang memaparkan secara terperinci terkait dengan objek penelitian.

Penelitian ini menggunakan metode penelitian kualitatif dengan analisis wacana kritis Norman Fairclough. Pandangan Fairclough mengenai analisis wacana kritis adalah bagaimana bahasa menyebabkan kelompok sosial yang ada bertarung dan mengajukan ideologinya masingmasing. Pandangan Fairclough terbagi atas tiga tradisi, yaitu (1) dimensi tekstual (mikrostruktural), (2) dimensi kewacanaan (mesostruktural), dan (3) dimensi praktis sosial budaya (makrostruktural). Penelitian ini ingin mengeksplorasi wacana mengenai isu yang diproduksi culture meme di media sosial. Dalam analisis wacana dibongkar makna yang terdapat dalam meme melalui dimensi tekstual. Analisis tingkat makro yang didasarkan pada pendapat bahwa konteks sosial yang ada di luar media yang memengaruhi bagaimana wacana yang ada ada dalam media.

Sebagai penelitian yang bersifat
deskriptif-kualitatif, penelitian ini tidak menggunakan hipotesis sebagai jawaban alternatif terhadap permasalahan yang diajukan sebagaimana yang lazim dilakukan dalam penelitian kuantitatif. Namun, hipotesis itu hidup dalam pikiran peneliti yang digunakan sebagai tuntunan dalam melakukan penelitian ini. Landasan teoretis dalam kajian pustaka tidak dimaksudkan sebagai dasar yang mengikat gerak peneliti, juga tidak bermuara pada hipotesis alternatif tertentu yang perlu diverifikasi dengan data empiris. Teori yang disajikan lebih berfungsi sebagai dasar berpijak dan bekal wawasan yang memandu peneliti dalam menggeluti objek penelitiannya.

Berdasarkan rancangan penelitian ini, ada lima pokok yang dilakukan, yaitu (1) merumuskan masalah, (2) menentukan jenis data yang diperlukan, (3) menentukan prosedur pengumpulan data, (4) menentukan prosedur pengolahan data, dan (5) menarik simpulan. Sesuai dengan rancangan penelitian kualitatif, maka dalam menentukan subjek dan objek penelitian dijabarkan sebagai berikut. Subjek dalam penelitian ini adalah meme di media sosial, sedangkan objek penelitiannya adalah bahasa satire yang digunakan, baik dari segi pilihan kata (diksi) maupun kalimat.
Dalam penelitian ini digunakan metode dokumentasi. Metode dokumentasi merupakan salah satu metode pengumpulan data kualitatif dengan melihat atau menganalisis dokumendokumen yang dibuat oleh subjek sendiri atau oleh orang lain. Dokumentasi merupakan salah satu cara yang dapat dilakukan peneliti kualitatif untuk mendapatkan gambaran dari sudut pandang subjek melalui suatu media tertulis dan dokumen lainnya yang ditulis atau dibuat langsung oleh subjek yang bersangkutan berupa ungkapan satire dan sarkasme. Dalam hal ini peneliti mencatat dengan teliti ungkapan satire dan sarkasme yang terdapat dalam meme yang beredar di media sosial. Kemudian menganalisis dengan dibantu kajian pragmatik sebagai analisisnya. Adapun jenis data yang dikumpulkan melalui teknik pengumpulan data, yaitu kata atau kalimat yang mengandung bahasa satire. Adapun jenis data yang dikumpulkan melalui teknik pengumpulan data, yaitu kata-kata atau kalimat yang merepresentasikan gaya bahasa satire dalam kultur meme di media sosial, baik instagram, facebook, twitter, maupun lainnya. Teknik pengumpulan data ini memberikan arahan bagi peneliti dalam memperoleh data yang kemudian disusul dengan cara-cara menyusun alat bantunya, yaitu instrumen penelitian (Emzir, 2010). Data yang diperlukan untuk menjawab permasalahan yang dipecahkan adalah tuturan, kata, kalimat, gaya bahasa, gesture yang merepresentasikan gaya bahasa satire. Instrumen penelitian juga digunakan untuk mendukung teknik pengumpulan data dalam penelitian ini. Pemilihan instrumen ditujukan untuk menunjang penggunaan metode dalam pengumpulan data. Instrumen penelitian adalah alat atau fasilitas yang digunakan oleh peneliti dalam mengumpulkan data agar kegiatan penelitian berjalan lancar dan sistematis (Arikunto, 2006:160). Alat atau fasilitas ini penting bagi kegiatan penelitian. Tujuannya untuk mempermudah kerja peneliti, dalam arti peneliti lebih cermat, lengkap, sistematis, dan menghasilkan yang terbaik.

Analisis data dalam penelitian ini menggunakan prosedur analisis data kualitatif. Secara umum analisis data dengan menggunakan model tersebut mencakup tiga tahapan, yaitu (1) reduksi data, (2) penyajian data, dan (3) verifikasi atau penarikan simpulan. Ketiga tahapan tersebut saling berinteraksi, berawal dari pengumpulan data dan berakhir pada selesainya penulisan 
laporan penelitian. Semua tahapan tersebut memiliki keterkaitan proses satu dengan yang lainnya.

\section{Hasil dan Pembahasan}

Meme culture merupakan fenomena baru dalam dunia ilmu komunikasi, khususnya ketika dunia digital dan dunia maya hadir sebagai media dalam penyampaiannya yang serba cepat, serba instan. Meme sangat diminati dan dinikmati oleh berbagai kalangan karena kemudahan bahasa dan mengandung unsur jenaka di dalamnya. Menurut $\mathrm{KBBI}$, meme adalah ide, perilaku, atau gaya yang menyebar dari satu orang ke orang lain dalam sebuah budaya. Atau bisa juga cuplikan gambar dari acara televisi, film, dan sebagainya atau gambar-gambar buatan sendiri yang dimodifikasi dengan menambahkan kata-kata atau tulisantulisan untuk tujuan melucu dan menghibur. Meme sebenarnya telah ada sejak ribuan tahun yang lalu. Namun, belum banyak yang mengetahui maksud atau makna sebenarnya yang terdapat di meme sehingga dapat menunjang kita dalam berkomunikasi.

Berikut beberapa meme di media sosial yang mengandung makna satire dalam kalimat atau diksi yang dipilih oleh sang pembuat meme di media sosial, baik instagram, facebook, twitter, berita online, maupun lainnya.

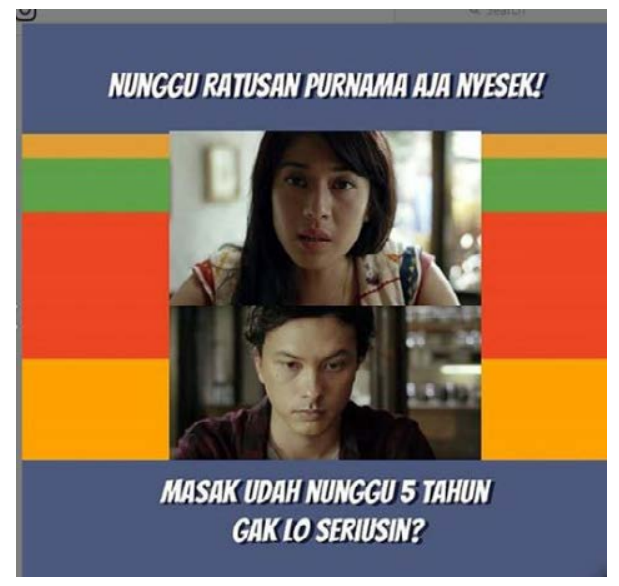

Data1

Meme pada data nomor 1 ini beredar di media sosial tepat dua hari sebelum pemilihan presiden secara langsung tahun 2019. Konteks yang melatarbelakangi kemunculan meme di atas, yaitu mencegah adanya pemilih yang golput serta semua masyarakat Indonesia yang sudah memenuhi persayaratan untuk dapat menggunakan hak pilihnya dengan datang ke tempat pemilihan. Hal ini dikampanyekan agar Indonesia mendapatkan pemimpin terbaik.

Dilihat dari segi diksi yang dipilih, yaitu ratusan purnama yang seolah melekat merek film tertentu dianggap ampuh untuk menyerukan sesuatu oleh sang pembuat meme.

Gaya bahasa satire juga tak luput disematkan pada meme di atas. Penggunaan kalimat yang fenomenal dalam salah satu adegan film Ada Apa dengan Cinta 2 tampak menjadi sindiran tertentu. Nunggu ratusan purnama aja nyesek. Masak udah nunggu 5 tahun gak lo seriusin? Kalimat ini menyindir sekaligus menyerukan kepada generasi, khususnya generasi muda dan yang hendak golput. Pemilihan presiden berlangsung lima tahun sekali ini harus dirayakan dengan penuh kesadaran bahwa Indonesia membutuhkan pemimpin terbaik di negeri ini. Sayang sekali jika warganya tidak menggunakan hak pilih tersebut. Pemilihan umum merupakan hal yang serius sebab menentukan nasib bangsa dan rakyat selama lima tahun ke depan. Jika salah memilih pemimpin, rakyatlah yang akan rugi atau sengsara. Dengan padu padan gambar adegan Rangga dan Cinta yang beradu debat semakin membuat satire dalam meme di atas tampak sangat nyata. Satire sindirian sekaligus pengingat bahwa pesta demokrasi sebentar lagi akan berlangsung dan saatnya menetukan suara.

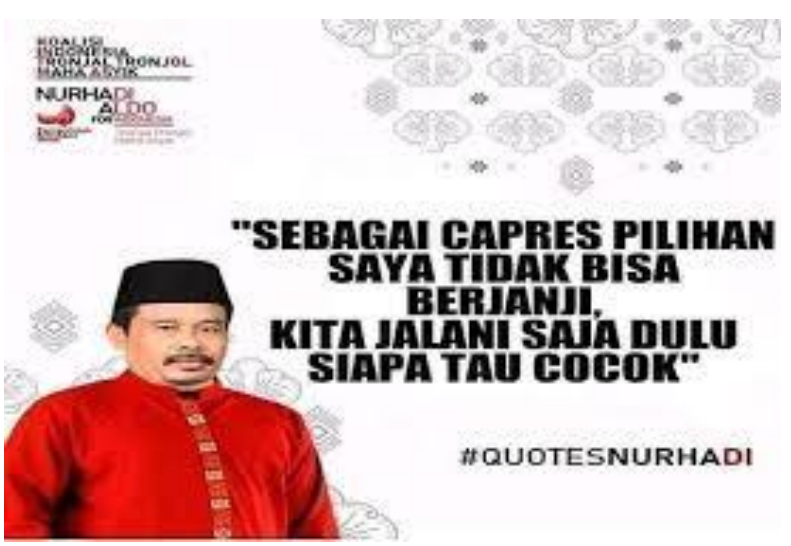

Data 2

Meme ini dibuat sebagai calon presiden dan wakil presiden tandingan yang sejatinya hanya dimaksudkan untuk menghibur dunia perpolitikan yang sedang tegang-tegangnya. 
Kehadiran capres dan cawapres imajiner, yaitu pasangan Nurhadi Aldo memang dibuat untuk meneduhkan suasana politik di Indonesia. Meme Nurhadi Aldo ini beredar luas di dunia maya. Isinya adalah kampanye dengan bahasabahasa politikus, tetapi bisa membuat seseorang menertawakan dirinya sendiri. Meme kampanyenya pun sangat menggelitik. Banyak hal konyol dan bernada satire yang turut meramaikan pertarungan politik pada tahun 2019. Kutipan meme di atas adalah salah satu di antaranya. Bahasa yang digunakan dalam meme nomor 2 bernada satire, yaitu terdapat sindiran kepada wakil rakyat yang banyak berjanji, tetapi setelah terpilih, kadang melupakan janji tersebut. Bahasa yang dipilih pada akhirnya yang bermaksud untuk menyindir, yaitu sebagai capres pilihan saya tidak berjanji. Kalimat tersebut bernada gaya bahasa satire sebagai fungsi sindiran. Sindiran terhadap wakil rakyat, baik dalam pemilihan presiden, DPR, DPRD, maupun pimpinan di tingkat lokal lainnya.

\section{Meme nomor dua berdasarkan analisis} diksi dan kalimatnya, secara implisit menyampaikan bahwa tidak ada calon pemimpin yang berkampanye tidak dengan janji atau berjanji. Semuanya mengumbar janji manis agar dapat simpati rakyat untuk melanggengkan kuasa atau merebut kursi pimpinan. Di antara yang berjanji tersebut, banyak yang menepati. Namun, tidak sedikit pula yang akhirnya ingkar terhadap janji tersebut. Untuk itu, kehadiran media sosial dapat menjadi tempat merekam segala bentuk janji, segala bentuk kampanye yang dilakukan oleh para calon. Jika nanti ada janji yang belum ditepati atau ada janji yang diingkari, hal itu akan dimunculkan kembali oleh netizen, baik dalam bentuk meme, slogan, maupun yang lainnya. Pilihan bahasa yang lain, yaitu Kita jalani saja dulu, siapa tahu cocok adalah gaya bahasa satire yang bermaksud untuk menghibur. Dalam meme ini ada semacam persamaan antara pemilihan presiden dengan pemilihan pacar atau suami istri dalam sebuah hubungan. Hal ini tentu menggelitik. Jika cocok, seseorang dapat menjalin hubungan yang mesra dan kekal. Begitu pula sebaliknya. Hal ini tentu dimaknai sama dengan pemilihan presiden yang langsung dipilih oleh rakyat dengan hati nurani, tanpa pemaksaan agar mesra dan selaras dengan rakyat. Bedanya, ketika menjalin sebuah hubungan asmara, jika tidak cocok, di tengah jalan dapat langsung bubar atau putus tanpa banyak hal yang perlu diselesaikan. Jika saja dalam pemilihan presiden atau pimpinan lainnya, ternyata tidak cocok dengan kehendak rakyat di tengah jalan, dapat putus atau diberhentikan seketika tanpa banyak riuh.

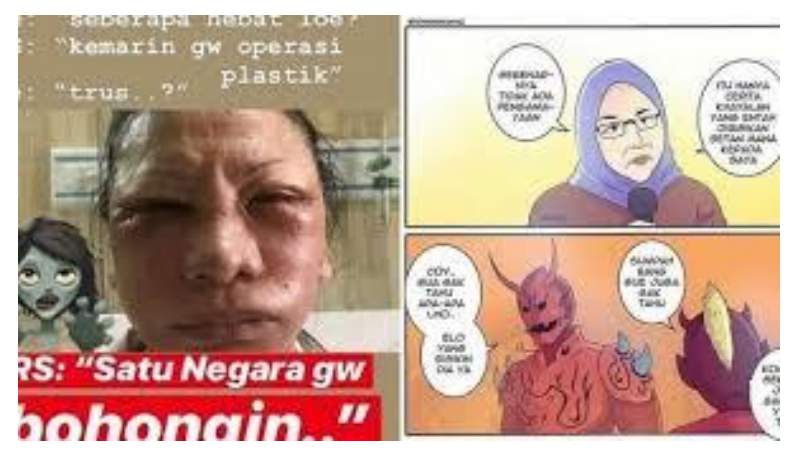

Data 3

Dipandang dari segi analisis teks, khusunya dalam pilihan kata atau diksi, meme nomor tiga ini dapat dijelaskan sebagai berikut. Indonesia sempat gempar dengan adanya kabar penganiayaan terhadap aktivis perempuan era tahun 1998, yaitu Ratna Sarumpaet. Ratna menyatakan bahwa dirinya dikeroyok oleh beberapa orang yang tidak dikenal. Berita penganiayaan itu cepat tersebar dan mengundang simpati seluruh rakyat Indonesia. Kondisi wajah Ratna yang babak belur menjadi kekhawatiran tersendiri. Akhirnya, banyak politisi, pemimpin menyatakan keprihatinan dan mengecam aksi brutal tersebut. Hingga konferensi pers di manamana dikampanyekan bahwa siapa pun dalang pengeroyokan Ratna Sarumpaet akan diganjar dengan hukuman yang tidak main-main. Namun, sayang seribu saying setelah dilakukan penyelidikan, kabar tersebut ternyata hanya hoaks yang disebar oleh Ratna dan pendukungnya. Luka lebam yang ditunjukkan Ratna ternyata bukan hasil pengeroyokan, melainkan hasil operasi plastik yang dilakukan Ratna. Kabar hoaks ini pun sangat disayangkan oleh masyarakat dan ditanggapi nyinyir oleh masyarakat Indonesia. Banyak meme bermunculan. Semuanya bernada satire yang menggelitik. Salah satu di antaranya, yaitu meme di atas. Pilihan kalimat yang digunakan, yaitu seberapa hebat lo? Kemarin gue operasi plastik, satu negara gue bohongin. Gaya bahasa satire ini bermaksud menyindir Ratna dan kubunya yang telah melakukan pembohongan publik. Entah apa motif di balik berita bohong yang sengaja disebarnya, publik menjadikan kasus 
ini sebagai hal konyol dan ditertawakan banyak pihak. Meme di atas juga bermaksud mengingatkan publik bahwa memproduksi dan menebar berita bohong itu tidak ada gunanya, malah akan menurunkan harga diri seseorang dan dapat menyebabkan kehancuran dan perpecahan bangsa.

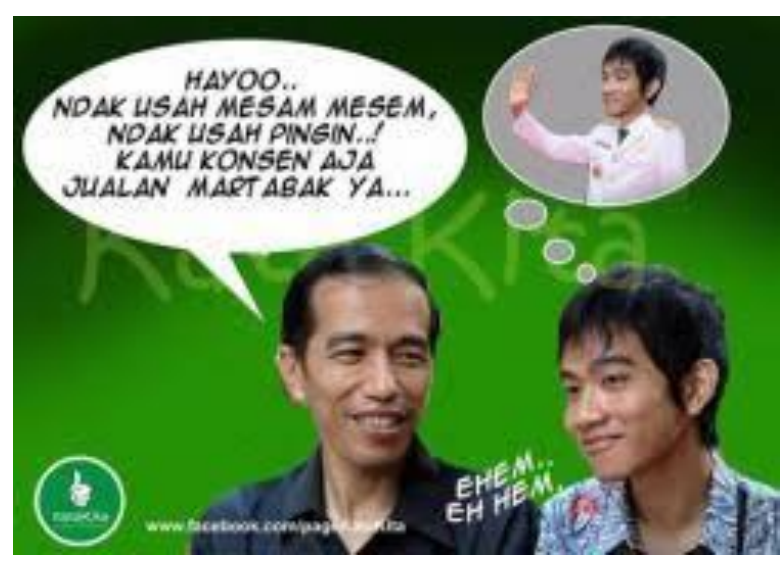

Data 4

Meme ini diunggah di salah satu akun media online. Meme ini memuat bahasa satire dalam kalimat sindiran berikut Hayoo, ndak usah pingin. Kamu konsen aja jualan martabak. Konteks yang melatarbelakangi pembuatan meme ini terkait dengan kebiasaan atau kecenderungan pemimpin tinggi di negeri ini menggunakan kekuasaannya untuk sebesar-besarnya kepentingan dirinya sendiri dan keluarganya. Tidak jarang yang menjadi pucuk pimpinan seakan menghendaki dinasti kepemimpinan dan kelanggengan kekuasaan. Di Indonesia sendiri banyak dijumpai jika sang ayah adalah politisi, pemimpin negeri, atau pemimpin daerah, anaknya pun ikut terjun dalam politik dan menjadi penguasa nantinya. Namun, kecenderungan tersebut seolah dibantah oleh kepemimpinan Presiden Jokowi yang meminta anak-anaknya, salah satu di antaranya Gibran Raka untuk tetap menjalankan apa yang dipilihnya terdahulu, yaitu berwirausaha, berjualan martabak. Meme di atas menyatakan sindiran, baik kepada pejabat terdahulu maupun yang akan datang bahwa jabatan tinggi bukan berarti harus memaksakan sanak saudara untuk menduduki jabatan setelahnya. Jika dipandang mampu, kemungkinan keluarga atau keturunan pemimpin negeri bisa jadi dikehendaki rakyat. Namun, bukan atas kehendaknya sendiri memaksa anak atau sanak saudara untuk ambil alih kekuasaan apalagi membentuk dinasti.

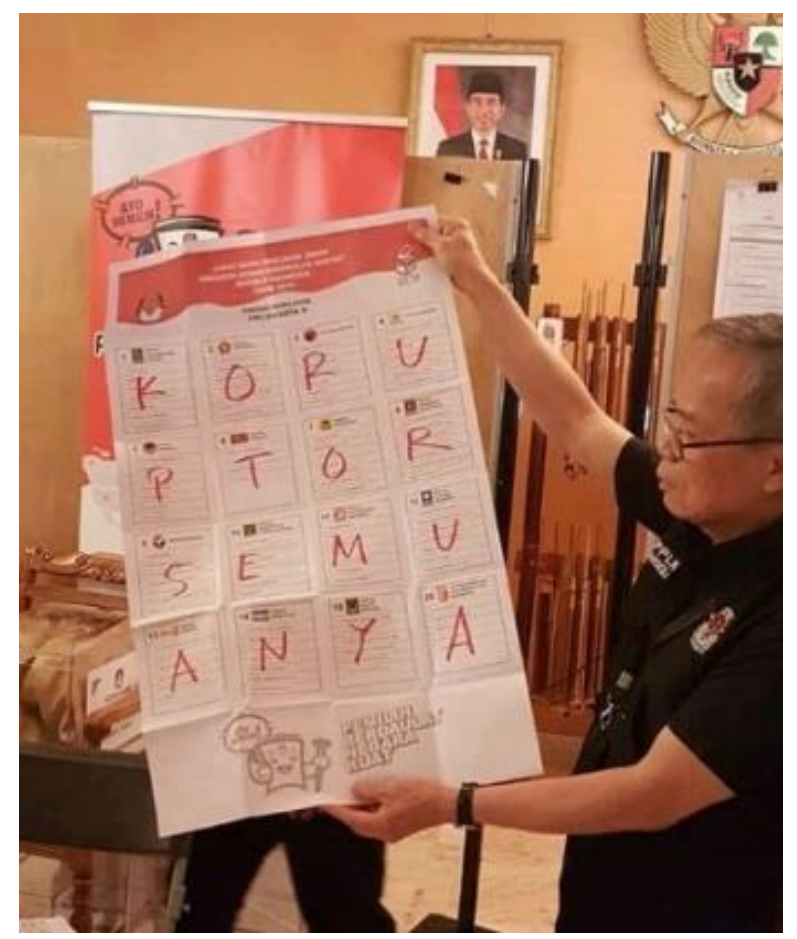

Data 5

Meme di atas memang tidak secara eksplisit memuat bahasa satire di dalamnya. Namun, tulisan koruptor semuanya dalam kertas suara yang hendak dicoblos nantinya seakan mengatakan satire dalam bentuk sindiran. Konteks yang melatarbelakangi pembuatan meme ini adalah terkait dengan keadaan yang memungkinkan seorang narapidana kasus korupsi ternyata masih dan dapat memiliki hak untuk dipilih kembali dan mengikuti pemilihan umum. Pembuat meme merasa bahwa hal tersebut tidak adil. Jelas-jelas sang calon telah memiliki citra yang kurang baik, apalagi terlibat kasus korupsi, maka dianggap tidak pantas untuk dipilih kembali menjadi pemimpin. Bahkan, untuk pimpinan dusun sekali pun. Ada juga partai yang tetap percaya diri memamerkan foto calonnya yang jelas-jelas telah tersiar pernah memakai rompi oranye dari KPK. Hal ini tentu dipandang tidak sesuai dengan misi penuntasan korupsi hingga ke akar-akarnya. Siapa yang dapat menjamin bahwa yang pernah jadi pesakitan kasus korupsi, begitu terpilih akan meniadakan sifat-sifat curang dan culasnya sebagai koruptor? Untuk membendung kembali terpilihnya calon mantan koruptor, dibuat meme dengan menyebut bahwa semua foto dalam 
kertas suara adalah koruptor. Dengan gaya bahasa satire tersebut, pihak-pihak terkait diharapkan dapat tersadar dan dapat menentukan pilihan terbaik untuk memimpin negeri ini.

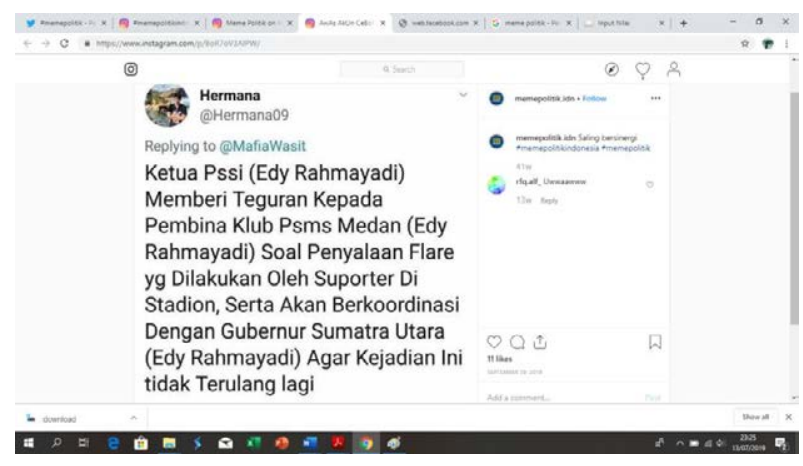

Data 6

Gaya bahasa satire dalam meme di atas tampak dalam kalimat bahkan paragraf yang dibentuk oleh sang penulis. Konteks yang melatarbelakangi munculnya meme ini adalah terkait dengan rangkap jabatan, rangkap tiga sekaligus yang terjadi pada sosok Edy Rahmayadi. Edy memenangi Pilgub Sumut 2018 dan dilantik Presiden Joko Widodo di Istana Negara, Jakarta Pusat, pada 5 September 2018. Per hari itu, Edy double job sebagai Ketum PSSI. Edy menegaskan rangkap jabatannya tidak mengganggu pemerintahan Sumut. Soal rangkap jabatan Edy, Kemendagri pernah mengimbau kepala daerah tidak menjadi pengurus di induk olahraga. Kemendagri mengatakan bahwa kepala daerah harus sepenuh hati mempertanggungjawabkan jabatannya. Seiring dengan berjalannya waktu, desakan agar Edy mundur dari Ketum PSSI bermunculan. Salah satu di antaranya dengan tagar Edy Out di medsos, menyusul hasil buruk timnas Indonesia di Piala AFF 2018. Tim Garuda gagal melaju ke babak semifinal setelah hanya menempati peringkat keempat di Grup B. Meskipun tekanan terus berdatangan kepadanya, Edy menegaskan tak akan melepas jabatan sebagai Ketum PSSI. Peristiwa rangkap jabatan ini sangat riuh ditanggapi oleh netizen. Keinginan Edy untuk tidak melepaskan satu jabatan pun akhirnya membuat citranya kurang baik dan menimbulkan kekacauan di ketiga tempat yang dipimpinnya. Kalimat satire yang dimaksud dalam meme di atas, yaitu satu orang bernama Edy melapor kepada orang yang sama bernama Edy, tetapi dengan jabatan yang berbeda. Jika lapor dengan orang yang sama, apakah akan ada penyelesaian? Bukankah yang terlapor dan melaporkan memiliki pemikiran dan jiwa yang sama, satu orang?

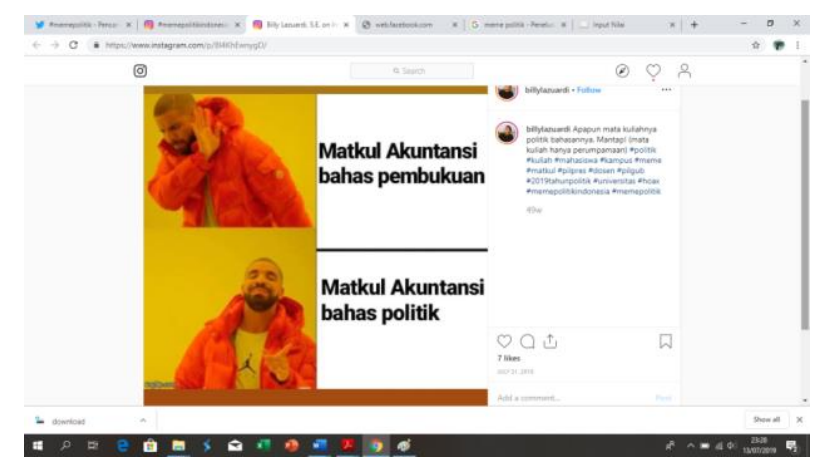

Data 7

Pemilihan Umum 2019 memang menyita perhatian masyarakat luas. Banyak yang terpecah karena politik. Banyak juga yang menjadikan politik sebagai bahan perbincangan yang lebih penting daripada apa pun. Masyarakat awam politik, masyarakat kelas menengah ke bawah juga berbicara soal politik. Hingga civitas akademika pun dituntut paham terhadap isu-isu politik dan tidak jarang menjadikannya topik dalam setiap mata kuliah. Meme di atas sengaja dibuat untuk menyatakan keadaan tersebut. Bukan hanya jurusan sosial politik yang berbicara tentang politik, jurusan-jurusan lain, termasuk akuntansi pun membahas urusan politik. Ada yang pro dan kontra terkait dengan menghadirkan sajian politik ke dalam kelas atau kampus. Yang pro tentu mendukung dengan alasan bahwa generasi muda harus memahami situasi politik di Indonesia dan mulai menentukan sikap terlepas apa pun jurusan ataupun mata kuliahnya. Yang kontra akan menolak sebab politik tidak dapat dimasukkan dalam pendidikan. Politik dan pendidikan merupakan dua hal yang jauh dan tidak saling berhubungan. 


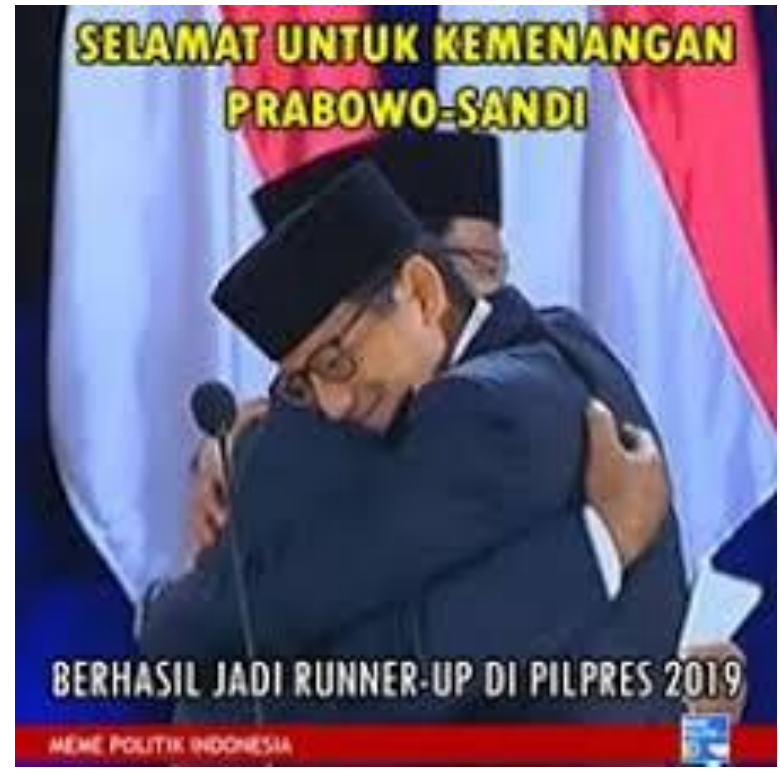

Data 8

Dalam kontestasi politik 2019, meme politik yang tersebar di media sosial cenderung mengangkat bahasa satire yang cukup menggelitik. Seperti salah satu meme di atas yang dimuat dalam media sosial instagram mengandung gaya bahasa satire. Kalimat yang dipilih seperti Selamat untuk kemenangan Prabowo Sandi berhasil menjadi runner up di Pilpres 2019 merupakan satire yang bermaksud menyindir. Pilihan kata runner up di meme tersebut menyatakan bahwa kubu Prabowo Sandi memang menang, tetapi menjadi juara kedua dalam Pemilihan Presiden 2019. Konteks yang melatarbelakangi kemunculan meme di atas, yaitu klaim kemenangan sepihak yang dilakukan oleh pihak terkait terhadap hasil pemilu. Padahal, dalam hitungan cepat, kubu terkait dinyatakan kalah. Salah satu kubu belum dapat menerima kekalahan, malah mendeklarasikan kemenangan sepihak tersebut dan menyatakan kemenangan dengan cara yang berlebihan. Banyak netizen di dunia maya yang berkomentar bahwa pasangan tersebut tidak siap menerima kekalahan dan sangat ambisius untuk menjadi presiden Indonesia. Karena geram dengan deklarasi kemenangan sepihak tersebut, tanpa menunggu pengumuman yang nyata dan terpercaya, netizen ramai-ramai mengucapkan selamat dengan nada satire, menyindir. Selamat menjadi juara kedua, selamat atas kekalahan yang berulang, serta meme selamat lainnya yang menyatakan arti sebaliknya, yaitu kegagalan.

\section{Simpulan}

Pembahasan di atas dapat disimpulkan bahwa dalam kultur meme politik di media sosial yang tersebar tersebut mengandung gaya bahasa satire yang berfungsi untuk menyindir, mengkritik dengan humor. Penggunaan bahasa dan kalimat yang dipilih benar-benar menggelitik sesuai dengan karakteristik meme yang sesungguhnya. Dengan adanya alat komunikasi meme dalam dunia digital seperti pembuatan meme ini, wadah kreativitas mengkritik lebih terbuka dan lebih bervariasi. Meme dapat menjadi humor juga bahan perenungan atas kenyataan yang terjadi. Oleh karena itu, meme menjadi respons baru atas peristiwa-peristiwa nasional, khususnya dalam politik. Meme memperjelas sikap kritik dan sindiran, tetapi dapat pula menghasilkan sindiran dan kritik dalam humor.

\section{Daftar Pustaka}

Arikunto, Suharsimi. 2006. Prosedur Penelitian : Suatu Pendekatan Praktik. Edisi Revisi VI. Jakarta: PT Rineka Cipta.

Chaer, Abdul dan Leonie Agustina. 2004. Sosiolinguistik: Perkenalan Awal. Edisi Revisi. Jakarta: PT Rineka Cipta.

Emzir. 2010. Metodologi Penelitian Pendidikan: Kuantitatif dan Kualitatif. Jakarta: Rajawali Press.

Eriyanto. 2001. Analisis Wacana. Yogyakarta: Lkis.

Fairclough, Norman. 1995. Critical Discourse Analysis: The Critical Study of Language. Harlow: Pearson.

Haryatmoko. 2016. Critical Discourse Analysis (Analisis Wacana Kritis): Landasan Teori, Metodologi, dan Penerapan. Jakarta: Rajawali Pers

Kunia, Dedi. 2012. Media dan Politik. Yogyakarta: Graha Ilmu.

Mahsun. 2007. Metode Penelitian Bahasa. Jakarta: PT Raja Grafindo Persada.

Pahrun, Rendy Wadipalapa. 2015. "Meme Culture \& Komedi-Satire Politik: Kontestasi Pemilihan Presiden dalam Media Baru". Jurnal Ilmu 
Komunikasi VOLUME 12, NOMOR 1, Juni 2015: $1-18$.

Rahmiati, Dyah. 2011. Satire Politik dalam Lagu "Andai $\mathrm{Ku}$ Gayus Tambunan". Jurnal JP Komunikasi.

Suhardi, B. 1996. Sikap Bahasa: Suatu Telaah Eksploratif atas Sekelompok Sarjana dan Mahasiswa di Jakarta. Depok: Fakultas Sastra UI.
Sumarsono. 2011. Sosiolinguistik. Yogyakarta: Pustaka Pelajar.

Sumarsono dan Paina Partana. 2002. Sosiolinguistik. Yogyakarta: Penerbit Sabda.

Suciartini, Ayu Ni Nyoman. 2019. "Analisis Bahasa Satire dalam Pertarungan Politik 2019". Jurnal Sirok Bastra Vol.7 Nomor 01 Juni 2019.

Suminar, Agustina. 2017. "Wacana Satire Politik dalam Situs Mojok.co". 